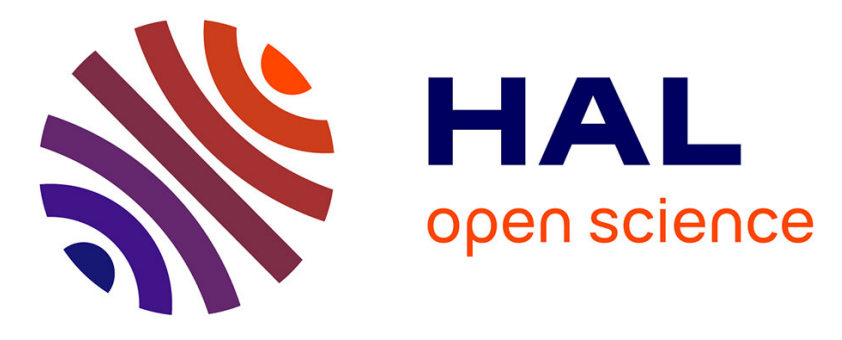

\title{
The determinants of military expenditures
}

Jacques Fontanel, Ivan Samson

\section{To cite this version:}

Jacques Fontanel, Ivan Samson. The determinants of military expenditures. Jacques Fontanel; Manas Chatterji. War, Peace and Security, 6, Emerald, pp.125-132, 2008, Contributions to conflict management, peace economics and development, 978-0-4445-3244-2. 10.1016/S1572-8323(08)06008-6 . hal-02068194

\section{HAL Id: hal-02068194 \\ https://hal.univ-grenoble-alpes.fr/hal-02068194}

Submitted on 14 Mar 2019

HAL is a multi-disciplinary open access archive for the deposit and dissemination of scientific research documents, whether they are published or not. The documents may come from teaching and research institutions in France or abroad, or from public or private research centers.
L'archive ouverte pluridisciplinaire HAL, est destinée au dépôt et à la diffusion de documents scientifiques de niveau recherche, publiés ou non, émanant des établissements d'enseignement et de recherche français ou étrangers, des laboratoires publics ou privés. 


\title{
THE DETERMINANTS OF MILITARY EXPENDITURES
}

\author{
JACQUES FONTANEL and IVAN SAMSON
}

in

\author{
Contributions to Conflict Management, Peace Economics and \\ Development v6 \\ J.Fontanel, M. Chatterji Editors \\ Emerald Publications \\ London, New York, New Delhi
}

\section{INTRODUCTION}

The increase in the military expenditure of the United States was committed since 2000, after several years of reduction. As well as the tax cuts, the military expenditure contributes largely to the current rise of the American public deficit. Considerable appropriations were granted to armament industries, such as for example the launching of the program of fighters F-35, for an amount of 220 billion dollars (for 3000 apparatuses). American rearmament since 2000 again reversed the tendency, digging the technological "gap" between American industry and the rest of the world. With the Afghanistan and Iraq wars included, the USA military expenditures represent $50 \%$ of the world expenditures.

What are the main explaining factors of the constant increase in the American military expenditures? The peaks observed before 1991 were clearly connected with the reactivation of cold war. Could a process of interaction with "enemies" also explain the current rise? What is the share of internal determinants in the process of resource allocation to the military budget? The methods of economic analysis may bring some explanations. The models of arms race in particular could be revisited from the current point of view, for a better understanding of the current level of the American military expenditures.

\section{THE EXPLANATION BY ARMS RACE}

Arms race is a dynamic process of competitive increase in quantity and/or quality in the armaments by two or several States, resulting from conflict objectives or mutual fears between nations.

However several criticisms of these approaches arise from the insufficient taking into account of the internal determinants of the military expenditures. In particular econometric tests generally did not make it possible to validate the thesis of the determination of defence budget levels by the mutual stimulation of States. The national self-stimulation is often more important. Several analyses of the Marxist thought explain why military expenditures are certainly unproductive but nevertheless essential with the correct operation of capitalism, insofar as they make it possible to fight against 
underemployment and production overcapacities. The point is the State intervention to support the average profit rate in the whole economy. Other analyses went in the same direction, in particular those of Galbraith. In fact, the economic importance of the military sector in certain capitalist economies seems indisputable today, would be this only shown by the share of military R\&D in the development of advanced technologies.

In the 1960s, arms race models enabled the come back of the influence of economic variables in the strategic decisions of national security. The model of Richardson (1960), based on three equations respectively representing the political, the strategic and the economic factor, constitutes the basic model. It describes the processes of armament of two rival countries as a process of action and reaction, where economic variables play a stabilizing effect. It introduces the military expenditures of the enemy or the enemies, the economic burden (the fatigability effect) and the "objections" (explaining historical phenomena). Richardson estimates that the arms race of the First World War was pushed by nationalist ambitions of annexation or recovery of territories, and not only by the response to the increases in armaments of the adversary. This is why he supplements his model with the coefficient of "objection" (grievances).

This theoretically interesting model did not explain anything of the last trends in world military expenditures. It was not able to analyse the crisis of the Soviet Union because the fatigability threshold is not easy to determine. The curves which define the sets of the "best possible choices" for a nation, given the level of the military expenditures of the adversary, are not significant in reality for several reasons: the difficulty in defining the military expenditure, their various structures, the nuclearization or not of the armies, the existence or not of the conscription, etc. The theories developed by Brito and Intriligator (1995) on the basis of mathematical optimisation under constraints, or the theories of the duopoly and the game theory are no longer in use today.

These models of arms race tend to separate the economic considerations of profit from strategic considerations, forgetting to specify the structural characteristics of the studied economies. They made the implicit assumption of the similarity of rival States. However the "requests for military expenditures" are different according to the types of political regimes. The fatigability effect of the planned USSR was certainly not the same one as that of the American market economy. The cost of the new wars is much lower than that of the conflicts of the cold war. The American-Soviet arms race, started again by R. Reagan at the beginning of the 1980s, has exhausted the economy of the USSR and has involved the collapse of the Soviet world.

The current asymmetrical conflicts do not require the same level of financial resources. They give a "sedentary" justification to the increase in the military expenditures. They refute internal factors like the existence of a military-industrialist complex and growth promoters of military expenditures. They do not integrate alliances, common policy decisions of regional security, etc. Today, there is no longer arms race. If there is one, it is the USA against the whole world. This is very asymmetrical and it is not always very easy to understand.

In the current international economic context, marked by the globalisation and the formation of powerful regional economic blocks around the main economic powers, certain countries could be tempted to conquer by the force the access to the wealth that was so far impossible to reach because of wild international competition and barriers to entry for the industries generating the highest added value. To take into account these predation strategies requires putting the question of the economic determinants of the conflicts again at the centre of the analyses of armament strategies, whereas it was 
isolated in the cold war models. The question arises for Iraq. Is there something like an attempt of oil predation or regulation, among other considerations? May be history will provide some answers in 20 years...

Whereas arms races opposed actors historically comparable, it is probable that the arms races of the next century will be of very different nature, between countries with high technology weapons and countries with basic technologies. They will be then asymmetrical arms races. However, the technological superiority is not a guarantee of security or of victory in the event of war, in a context where the democracies of the industrialised countries aim at minimising the number of their losses in the combat.

\section{NEW THREATS}

The phenomenon of terrorism forces to reconsider the military models of expenditures. In particular, the rationality of the actors, which is presupposed to several economic models, is questionable. One may wonder whether there it is not a strong limitation in the analyses of terrorism by methods exclusively borrowed from economic "pure" science. The asymmetry of information (for example about the level of armament of the adversary) must be taken into account. Vis-à-vis the terrorist threat, it is no longer the observation of the military expenditures of the adversary that determines their level in a country, but rather the perception of a threat. The quantification of this threat is problematic: the identification of "rogue States" by the United States gives an indication

Since the attacks of September 11, 2001, the presidency spoke explicitly about "war against terrorism" and planned to increase the military expenditures, undoubtedly up to the levels reached at the time of the former episodes of diplomatic tensions (Korea and Vietnam wars, as well as "Star Wars). However all the components of the military expenditures are not affected in the same manner by the evolution of the geopolitical context. Thus, the expenditures for military R\&D are less sensitive to the geopolitical evolutions but remain nevertheless upwards oriented. According to estimates in constant 2004 dollars, the item of expenditure of RDT\&E (research, development, test and evaluation) showed the strongest increase since 1980 and this trend is expected to continue at least until 2010.

Economic globalisation made the countries the most industrialized more vulnerable to the attacks, because of the globalisation of the communications, the rise of transport (in particular air travels), the concentration of population and resources in urban areas, etc. Terrorist methods benefit from the advantage of not having to take into account the support of large civil populations, which was the problem that guerrillas faced. Terrorist war achieves its goal by attacking the civil populations of the target countries, while using the opportunities provided by their logistics and their infrastructure.

\section{THE MEMBERSHIP TO AN ALLIANCE}

The analysis of the American military expenditures must also take into account the membership of the country to strategic alliances and in particular that of NATO. Indeed, because of the variety of foreign policy instruments (diplomatic operations, interventions in regional conflicts, economic and military aid, membership to an alliance), the only consideration of the reaction of the military expenditures of a State to those of a rival State is insufficient. The membership to an alliance is one of the 
explanatory variables of the level of military expenditures of a country. Alliances represent the decentralised production of public ownership generating new externalities. Many economists were interested in the analysis of alliances like public goods, and in the relation between interstate alliances and the pacification of the relations between the Member States. These approaches are based on the contribution of Olson and Zeckhauser (1966) and use the concepts developed by the game theory. It appears today that the main obstacles to the optimal operation of an alliance remain identical to those that have been identified in the above model. Thus, because of the free-rider problem the higher is the number of members who could benefit from the collective action, the lower are the chances that the good is provided in an optimal way. In addition, asymmetries within the group (regarding the size of the countries or of their level of richness) can lead to "the exploitation of the large one by the small one", for example if the small countries choose a "free-rider" behaviour. Current studies on alliances generally show that the dysfunctions of collective action (increased difficulties in the event of military crises, decrease in defence budgets because of increased confidence in Member States) can be corrected by institutional arrangements and the installation of a system of selective incentives. However the perverse effects are still dominating. Washington financed the Alliance initially, but, by this way, the United States controlled the main instruments of the international security. Today, there is a temptation to stop this cooperation, but NATO is financially and militarily a good alliance for the USA (Fontanel, Coulomb, 2007).

\section{THE EXISTENCE OF A NATIONAL ARMAMENT INDUSTRY}

Moreover, the studies on the defence industry basis (or military-industrialist basis) developed since the 1960s tend to show that there is a phenomenon of growth of the costs of the military production that involves a rise in defence budgets. Spinney (1996) showed that from 1953 to 1992, the average cost of a military aircraft in the United States increased faster than the total military expenditures of this country. The increasing sophistication of the armaments, as well as the particular characteristics of the contracts in the armament industry, explain this phenomenon. Mary Kaldor (1981) highlighted this trend as "the baroque arsenal".

The importance of defence industries in the national economy is one of the determinants of the level of military expenditures of a country. Admittedly, many hopes of obtaining the "dividends of peace" appeared in 1991 with the collapse of the Soviet Union, which seemed to open the way to a durable international disarmament. Specific military knowledge has few civil applications. The concept of "dividends of peace", very popular during the cold war, was replaced by that "of investment of peace" revealing the costs associated with the discontinuance of defence business. The crisis of the armament markets at the beginning of the 1990's imposed the deep restructuring of American armament industries initiated by the authorities, leading to the birth of four major firms. The American defence industry represents today half of world armaments exports for a value of 14.2 billion in 2003 (and a sales turnover of 120 billion dollars in 2001). It seems today that the defence companies use more and more subcontracting and the membership to industry networks or alliances, the consortium for Joint Strike Fighter being illustrative of this trend. Moreover, defence companies realise a significant part of their sales turnover in the civil sector, which enables them to limit the risks associated with budget restrictions in the field of defence. That may undoubtedly ease the transfers 
between military and civil sectors for human and physical capital, technologies or products.

\section{IMPORTANCE OF THE MILITARY R\&D}

The issue of the impact of military expenditures on economic growth is one of the stakes of the debate between the partisans and the opponents of a cut in military expenditures. The question of the impact of the military $R \& D$ on the growth of the manufacturing productivity is polemical. Indeed, the technologies originally developed for defence, such as computers or satellite communications, seem to have generated an important share of the American growth during 1990s. The econometric studies that were developed these last years however do not show in a decisive way any link between the growth of the American manufacturing productivity and the development of these new technologies.

The analysis of D. Saal (2001) shows that sophisticated econometric methods may highlight the positive effect of the federal R\&D expenditures on the global manufacturing productivity since the 1970 s. In 2002, 54.4\% of national R\&D expenditures were devoted to military R\&D in the United States (against 24.2\% in France for example). The financial volume of the American military R\&D rose to 53 billion dollars in 2003 (against 44 billion in 2000). In addition, $10 \%$ to $15 \%$ of the American military expenditures are used for financing fundamental research, contributing to R\&D increases in the advanced technologies.

Thus, the use of the military expenditures for "industry policy" purposes can be regarded as one of the explanatory factors of their level in the United States. In the same way, the increasing use of information services for economic purposes may benefit from the level the military expenditures, especially in the United States where the apparatus of economic intelligence is particularly developed.

\section{THE STATE BUDGET GROWTH}

The level of the defence budget of a country is depending on several internal variables. One may consider that the optimisation of the social wellbeing by the allocation of resources to defence is not guaranteed by the procedure of collective choice because of the divergence of interests between the various groups or individuals composing the society. The "Public Choice" theory developed in the 1970s makes it possible to explain why, in certain cases, the policy conducted by the government does not use all the potentialities for increasing the social wellbeing. The State is the sum of the particular interests of groups or individuals and its intervention is the result of the pressures of specific lobbies, each one seeking to maximize its own utility. The models of Public Choice try for example to show a relation between political cycles and the signature of contracts with defence industries. They denounce the bureaucratic growth, which leads to dysfunctions such as the undervaluation of the costs of projects. A large latitude is often left to the decision makers to interpret the national preference as regards defence policy. Various lobbies (defence industries, political parties, State bureaucracies, consumer lobbies, international agencies...) try to influence the defence policy in the way which is favourable for them. 
More largely, the analysis of the determinants of the American military expenditures leads to raise the question of the determination of the request for defence. How is the perception of threat determined? Which are the variables that help a government identifying the "request for defence" specified in the models of military expenditures? The military expenditures of a country during one year depend on those of the previous year: it is the phenomenon of "budgetary inertia" used in certain models of military expenditures called "bureaucratic models". The analysis of the defence budget of the United States must thus take into account this reality.

The Charter of the United Nations demilitarization implies respect for the sovereign equality of its Member States, prohibition of the use of force or the threat of its use against the territorial integrity of States, recognition of the inviolability of frontiers, renunciation of any action against independence and national unity, non-intervention in the internal affairs of other States and not giving assistance to terrorism. However, States still have a significant role in economic governance. The emerging powers of international markets, which reduce the State exclusive control of territory, do not neglect the national government, but they modify their functions, with much less sovereign entities and much more components, giving it a legitimacy role, of the international body. Because people are less mobile than money, goods or ideas, the territorial control, with the monopoly of the means of violence, is still dominated by States. States guarantee national security to citizens from external and external conflicts.

Conflicts find expression in economic, political and cultural domination. In an increasingly interdependent world, geopolitical considerations involve a definition of security that is both economic and military. Underdevelopment is a threat to world peace. And despite the internationalization of financial markets and the increasing importance of international trade, it is not true that national economies are completely dominated by a global economy governed by world market forces. The world economic system is not ungovernable, because international organizations define rules and laws, which are more and more independent of the agreement of the States, but United States.

\section{BIBLIOGRAPHY}

Brito, D. and Intriligator, M. 1995. "Arms races and proliferation.” in ed. Hartley, K. and Sandler, T. Handbook of defense economics. Elsevier.

Fontanel, J. and Coulomb, F. 2007. "Les budgets de l'OTAN et ses missions" in Quel avenir pour l'OTAN sous le direction de Pierre Pascallon, Collection Défense. Paris : L'Harmattan.

Kaldor M. 1981. The Baroque Arsenal. New York : Hill and Wang.

Olson, M. and Zeckhauser, R. 1966. "An economic theory of alliances." Review of Economics and Statistics 48(3): 266-279.

Saal, D. 2001. "The impact of procurement-driven technological change on U.S. manufacturing productivity growth." Defence and Peace Economics 12(6): 537-568.

Spinney, F. 1996. "Defense time bomb: F22/JSF case study. Hypothetical escape options." Challenge 20: 23-23, July-August.

JACQUES FONTANEL: Professor of Economics, University of Grenoble, France Centre de Recherches Economiques des Politiques Publiques dans une Economie de Marché, Espace Europe - Domaine universitaire, 151 rue des Universités, BP 47 - 38040 Grenoble Cedex 9, email address: jacques.fontanel@upmf-grenoble.fr 
IVAN SAMSON : PhD in Economics, Senoir Lecturer, Director of Espace-Europe, University of Grenoble, France, Domaine universitaire, 151 rue des Universités, BP 47 38040 Grenoble Cedex 9, email address: ivan.samson@upmf-grenoble.fr 